\title{
SERVICE MIX OF SELECTED SERVICE SECTORS
}

\author{
K. Tharaka Rami Reddy*
}

Principal, Bapuji Academy of Management and Research, Davangere, Karnataka

\begin{abstract}
Product/Service mix is an important consideration for businesses that have large product or service lines. The proper product/service mix can increase sales by offering a product or service that will meet the demands of almost any consumer. A firm's product/service mix is particularly important in a competitive industry where there are multiple competitors competing for different customer segments. Services are products, even though intangible, they are things. And service marketers must always remember that consumers do not buy any products, they buy attributes that are converted into benefits. Many services are custom designed products. This has several implications for product planning and development. Intangible dominant products like services cannot be stored nor can they be transported, transported. But the service marketer none the less has a product development and merchandising task, which is to maintain a balanced assortment of goods to meet expected consumer demand. This study mainly concentrated on service mix of selected service sectors like Health care, Hotel and Tourism in Andhra Pradesh. Findings are discussed elaborately. Hypothesis is formed and tested to determine the relationship between selected service sectors as far as the reasons for selecting present service mix offered are concerned .Developing diversified Products / Services, Developing Infrastructure Facilities \& Diversified Products/ Services and Products / Services Differentiationare some of the suggestions made to improve the Service mix of selected service sectors.
\end{abstract}

Key words :Product/ service mix, consumer demand, diversified products

\section{INTRODUCTION:}

Service is a quite complex phenomenon where a number of researchers attempted to define the service, but no single definition has been accepted universally. It is necessary to look at various definitions given by scholars and experts so as to acquire clarity on the service concept. Services are products, even though intangible, they are things. And service marketers must always remember that consumers do not buy any products, they buy attributes that are converted into benefits. Like other consumer 'goods', services are convenience, shopping or specially goods with all that implies. There are two important things to note. First, a service is a bundle of features and benefits and secondly, these benefits and features have relevance for a specific target market. 
Therefore, while developing a service product must have a customer's perspective.

\section{REVIEW OF LITERATURE:}

Richard K.Thomas and Louis G. Pol (1993) highlighted the involvement of health demography in the advancement of the state of marketing in healthcare and reducing barriers that have retarded the development of mature marketing function within the health care industry. They say that health care industry must develop means for measuring "Quality" and evaluating the effectiveness of Product, Pricing, Promotional and Distribution decisions. They suggested that health care marketers must embrace the new field of health demography if they expect to keep their organizations competitive.

Ashish Chandra, Deborah C. Barbe and Ron Cheek, (1998), stated that, Health care products and services marketing is becoming an increasingly important component of organizations which deal in such products and services, which is expanding globally quite rapidly. Though promotion of over-the-counter prescription drug products directly to consumers is not a new concept, promotion of prescription drugs products and health care organizations directly to consumers is a relatively new concept. Increase in such promotional activities give rise to the possible legal implications of such activities. This paper attempts to provide in brief an insight regarding new marketing opportunities available to health care products and services marketers.

\section{Hilary Catherine Murphy and} Christian D Kiegast (2008), investigated how small- and medium-sized hotels use search engine marketing (SEM) to make their hotels (services and products) more visible and easier to find for existing and potential customers. A qualitative, exploratory approach is taken and eight case studies of small, independent hotels are conducted via in-depth, semi-structured interviews. These interviews reveal that though all hotels have a web site they do not exploit SEM, which may be attributable to poor marketing planning and lack of control of their web site through outsourcing key web development and optimization activities. The practical implications are that small hotels risk being marginalized, losing contact with their customers and fail to 
maximize their return on investment on their web site. They highlighted the critical issues and explored the potential to re-orient the small operator towards the opportunities of successful SEM and fully utilize their web site as a tactical and strategic marketing tool.

\section{METHODOLOGY:}

Objectives of the Study:

1. To study the service mix of selected service sectors.

2. To suggest ways and means, if needed, for strengthening selected service sectors for better service mix practices.

\section{Data Sources:}

This study requires both Primary and Secondary data.

\section{Data collection method:}

For collecting Primary data, a Questionnaire is used as Research Instrument followed by personal interview.

\section{Sampling:}

The samples were selected by using, Non-probability sampling procedure and in specific, Quota Sampling technique has been adopted to select the sample. To make the sample more representative of the entire state, sample has been selected from all the three regions of Andhra Pradesh namely Coastal region, Telangana region, and
Rayalaseema region. The questionnaires were distributed to the target respondent firms and after the scrutiny it was found that the collected questionnaires with the following numbers are found valid.

Healthcare service sectors $: 111$

Hotels and Lodges $: 114$

Tourism (Tour Operators and Travel Agents) : :108

Data Analysis:

The collected data is coded, tabulated and summarized. One-Way ANOVA, Chi-Square tests and Freidman test have been applied for analyzing the data.

\section{HYPOTHESIS TESTING:}

H0: There is no significant difference across the selected service sectors as far as the reasons for selecting the present Service mix offered are concerned.

With reference to reasons for selecting the present Service mix offered across the three selected services sectors, Chi- 
Square test is used to find any significant difference exists across the service sectors as far as the reasons for selecting the present service mix. It is found that calculated value is greater than critical value of chi-square in case of all three reasons. Thus Null Hypothesis $\mathrm{H} 1$ is rejected. (Table-1)

- It is understood that "most widely provided services are 'Emergency services' and 'Pharmacy services' by the Hospitals, 'Communication services' and 'shopping services' by the hotels and 'Transportation services' and 'Accommodation services' by the tourism firms. Rarely provided services are 'Ambulance services' by the hospitals, 'Personal care' and 'Boarding services' by the hotels and 'Recreation services' by the Tourism firms.(Table-2)

- Due to the reason 'Based on Professionals available', $90.1 \%$ of the hospitals, $79.6 \%$ of the Tourism firms and $57 \%$ of the Hotels are providing the present service mix to their customers.(Table-3)
- Due to the reason 'As per the customer requirement', $90.7 \%$ of the tourism firms, $69.3 \%$ of the selected hotels and $64.9 \%$ of the hospitals are providing the present service mix.The calculated Chi-square value is 22.188. At 5\% level of significance the critical value of chisquare for 2 degrees of freedom is.5.991. Since calculated value is greater than critical value of chisquare, it can be concluded that 'there is significant difference across selected service sectors as far as the reason 'As per the Customers requirement' for selecting the present Service mix offered is concerned.(Table-4)

- It is observed that based due to the reason 'As per the advices of the Directors/Owners', $74.1 \%$ of the tourism firms, $41.2 \%$ of hotels and $39.6 \%$ of the hospitals are providing the service mix to their customers.(Table-5)

- Regarding areas of services planning to add in their Product/Service mix by the service firms, from the above description it can be stated that " 
most widely planned areas of services are 'Diagnostic services' ,'Pharmacy services' and 'Casualty Services' by the Hospitals, 'Entertainment services', 'Lodging services' and 'Boarding services' by the hotels and 'Attraction services', 'Recreation services', 'Restaurant services', 'Accommodation services' and 'Shopping services' by the tourism sector.(Table-6)

- 'Ambulance services' are not provided by the maximum number of hospitals, 'Personal care, Shopping and Lodging services' are not provided by the maximum number of hotels, 'Shopping, Recreation and Restaurant services' are not provided by the maximum number of tour operators and Travel agents.(Table7)

- . It is understood from the table that, $64 \%$ of the hotels, $60.4 \%$ of the hospitals, $51.9 \%$ of tour operators and travel agents agreed with the reason 'Non availability of facilities and equipment' followed by $44.4 \%$ of tour operators and travel agents, $36.9 \%$ of the hospitals, $34.2 \%$ of the hotels agreed with the reason 'Non available of staff' and very few sample i.e., $2.7 \%$ of the hospitals, 1.8 $\%$ of the hotels, $3.7 \%$ of tour operators and travel agents agreed that there is 'No reason' for unable to provide the services.(Table-8)

\section{CONCLUSION:}

The study revealed that regarding Service mix offered by Healthcare, Hotel and Tourism sectors, many of the hospitals failed to offer full range of services to their customers. Based on availability of the professionals and Customer's requirements few selected services are like Emergency and Pharmacy services offered and other services are not provided in many of the hospitals. The reasons identified are lack of facilities, equipment and Staff.

All hotels have failed to offer full range of services to their customers. Based on availability of the Customer's requirements and professionals, few selected services are offered. Except communication services, Reception Services and Boarding services, other services like Personal care, Entertainment services are offered rarely. The reasons identified are lack of facilities and equipment. 
All the tourism firms are failed to offer full range of services to their customers. few Selected services are offered based on availability of the Customer's requirements, professionals and as per advises of owner. Except Transportation services and Accommodation services other services like Recreation, Shopping, Restaurant, and Attraction services are seen rarely. Lack of facilities, equipment and staff are the reasons identified.

\section{REFRENCES}

1. Ashish Chandra, Deborah C. Barbe and Ron Cheek, (1998), "Healthcare Products And Services Marketing: New Opportunities For Marketing Professionals", website: www.sbaer.uca.edu

2. Dr. Adarsh Batra (2006), "Tourism Marketing For Sustainable Development", ABAC Journal, January- April, Vol. 26, No. 1 Pp.5965.

3. Fotis C. Kitsios,(2006), "Services Marketing in the Hospitality Economy: An exploratory study"Paper presented at the $98^{\text {th }}$ EAAE Seminar 'Marketing Dynamics within the Global Trading System: New Perspectives', Chania, June - July.

4. Hilary Catherine Murphy and Christian D kiegast, (2008), "Do small and medium sized hotels exploit search engine marketing?"International Journal of contemporary Hospitality management , Vol.20, Issue: 1, Pp.90-97.

5. Jha S M (2003), "Services Marketing", $6^{\text {th }}$ edition, Himalaya Publishing house, Mumbai.

6. Kotler Philip and Paul N. Bloom (1984), "Marketing Professional Services" Prentice Hall, New Jersey, Pg.174.

7. Lumsdon L. (1997), "Tourism marketing", Oxford: International Thomson business press. 